\title{
Editorial
}

\section{Social Innovation and the Energy Transition}

\author{
Thomas Hoppe * $*$ and Gerdien de Vries \\ Organization and Governance (OG), Department of Multi-Actor Systems (MAS), Faculty of Technology, \\ Policy and Management (TPM), Delft University of Technology, Jaffalaan 5, 2628 BX Delft, The Netherlands; \\ G.deVries-2@tudelft.nl \\ * Correspondence: T.Hoppe@tudelft.nl
}

Received: 20 December 2018; Accepted: 21 December 2018; Published: 28 December 2018

\begin{abstract}
The transition to low carbon energy systems cannot solely rely on technological innovation. It also requires social innovation. In the context of energy transition social innovation can be defined as innovation that is social in its means and which contributes to low carbon energy transition, civic empowerment and social goals pertaining to the general wellbeing of communities. This article presents the editorial comment of the special issue "Social Innovation and the Energy Transition". It seeks to answer the questions, "what does social innovation mean in the face of energy transition, and what are its implications?" This special issue yields 20 article contributions by authors from different academic disciplines within the behavioral and social sciences. From these contributions, key topics relevant to social innovation emerge, pertaining to: (i) technological innovation leading to new market models, actor configurations, and institutional settings creating room for social innovation; (ii) new governance arrangements; (iii) community energy, its impact, implications, and social incentives and policy to empower it; (iv) new participative research approaches to test and learn from livings labs and best practices; (v) 'green nudges' to stimulate behavioral change; and (vi), serious energy games. The editorial ends with suggestions for future research.
\end{abstract}

Keywords: social innovation; energy transition; green nudge; community energy; community empowerment; renewable energy; energy governance; climate change mitigation

\section{Introduction}

Earlier this month (December 2018) the Katowice Climate Change Conference was held, officially known as the 24th Conference of the Parties to the United Nations Framework Convention on Climate Change (i.e., 'COP24'), [1,2]. It was organized to agree on the implementation of the Paris Agreement, which was adopted on 12 December 2015 at the 'COP21' in Paris. On 22 April 2016, the Paris Agreement was signed by 175 Parties (i.e., 174 countries and the European Union) to pursue efforts to limit global temperature rise to well below $2{ }^{\circ} \mathrm{C}$ compared to pre-industrial levels [3]. This means that a goal of zero net anthropogenic greenhouse gas emissions should be reached during the second half of the 21st century [4]. By signing the agreement, the signatory parties started to adopt its goals into their own legal and regulatory systems, making a shift toward low carbon economies with an emphasis on reduction of energy demand, use of renewable energy sources, and increasing energy efficiency levels. In other words, engaging in energy low carbon transition, from centralized energy systems using (foremost) fossil fuels to (more) decentralized systems using renewable energy sources to a greater extent. To make this happen, a radical change of current energy supply systems is required, which makes it necessary to change policy, social, and technical energy practices, while not only focusing on the supply side of energy markets but also on the demand side.

The changes that these transitions comprise cannot be accomplished while solely relying on technological innovation, as the uptake and use of the latter calls for new ways of organizing and 
governing energy supply and energy systems (and thus, regulatory response [5]). Moreover, there are many social and behavioral barriers-such as social acceptance of renewable energy projects (i.e., by community acceptance, socio-political acceptance, and market acceptance; [6]) —-that need to be overcome in order to propel energy transition. Resistance to renewables is usually rooted in social and behavioral concepts like attitudes and values, strategies and policies, organizational structures and processes, delivery systems, and services throughout existing energy systems [7]. Tackling these problems not only demands technological solutions (i.e., technological innovation) but also new ways of collaboration, decision-making, and of mobilizing society. This especially holds for renewable energy technology that typically has a disruptive and bottom-up nature [5].

In energy research, attention into the social and behavioral aspects of energy systems is often absent [8]. It is conducted separately from technical research, or it is only applied in a late stage of technological development. Moreover, novel energy technologies encounter challenges when it comes to societal acceptance and adoption [6,9]. Potential users, for example, have difficulties to adapt their behaviors when this is required for adoption and optimal use [10-12]. Another problem related to the social dimension concerns the resistance to energy innovations-for instance by incumbents in the industry, governmental bodies, traditional energy suppliers, or by local communities-who perceive these innovations as disruptive or even threatening, and seek for opportunities to slow down or co-opt their development $[13,14]$. This also pertains to existing institutions, that often impede the development and diffusion of promising sustainable energy innovations $[15,16]$.

A phenomenon that is often related to the social dimension of innovation (e.g., new ways of collaboration, decision-making, and of mobilizing society), is 'social innovation', broadly defined as, "new ideas that work in meeting social goals" [17] (p.8). In recent years, social innovation has received increasing scholarly attention, for instance on the concepts of community energy and renewable energy cooperatives [18-20]. For example, energy cooperatives that practice social innovation because they use new ways of decision making, in which technological developments go hand in hand with innovative ways of uniting different interests via cooperative decision making [21]. Social innovation can also be aimed at individual behavior, for instance in the form of green 'nudges': subtle modifications in people's decision context in order to gently move them towards sustainable choices without changing monetary incentives or an option set itself [22].

The objective of this guest editorial is to address 20 article contributions to this special issue (see for the full collection of articles: https:/ / www.mdpi.com/journal/sustainability/special_issues/ Social_innovations_energy_transition) and to use them as a conceptual and empirical basis to define and conceptualize social innovation in the face of energy transition. The research questions in this article are, "What does social innovation mean in the face of energy transition, and what are its implications?"

The special issue to which this guest editorial complements results from the "Social Innovation and the Energy transition" symposium which was held on 3-4 April 2017 at Delft University of Technology, in Delft, The Netherlands, and was organized by the Delft Energy Initiative, Platform on Social Innovation in the Energy Transition (see also: https:/ /www.tudelft.nl/en/social-innovation/).

This article is structured as follows. In Section 2, social innovation is introduced is a concept, and its meaning in the context of energy transition is defined. Next, in Section 3, the lessons from the article contributions to this special issue are highlighted, pertaining to disciplinary background, the use of theory and methods, insights vis-à-vis social innovation, and emerging issues. Finally, in Section 4, the conclusions and suggestions for further research are presented.

\section{Social Innovation: Conceptualization in the Context of Energy Transition}

Although a plethora of definitions exist innovation can basically be defined as, "new ideas that work" [17] (p. 8). In relation to energy, energy systems and energy transitions innovation usually bears the meaning of technical or techno-economic innovation (like new technology to generate energy, store energy or a new technology to make energy systems 'smarter'). Unlike other forms of innovation, 
social innovation includes the connotation of meeting social goals, i.e., new ideas that work in meeting social goals, like achieving a more equitable, just and empowered society $[23,24]$. More specifically, social innovation can be understood as, "innovative activities and services that are motivated by the goal of meeting a social need, and are predominantly developed and diffused through organizations whose primary purposes are social" $[17,25] ;$ p. 8).

As such, social innovation can have multiple meanings, for it is a concept that is considered hard to grasp [26]. This is highlighted in a statement by Bergman et al. [27] (p. 3), "The difficulty in defining social innovation is both because all innovation, including technical innovation, involves social processes, and because every social change could be described as innovative in one way or another". Acknowledging this, Cajaiba-Santana [28] distinguishes two ways of analyzing social innovation, each based on a separate theory. On the one hand, there is the individualistic perspective, which seeks to "find innovative solutions to social problems in one's community that are not adequately met by the local system". On the other hand, there is the structural perspective, which implies that structure and context are the main factors explaining innovation. From an analytical perspective social innovation is seen as going through some sort of process, which pertains to a limited number of concepts and stages. Hochgerner et al. [29] hold that social innovation moves through a '4i' process, which consists of: (i) conceiving ideas, (ii) making an intervention, (iii) implementation, and (iv) resultant (social) impact.

There are several characteristics that pertain to social innovation, and distinguish it from other types of innovation. Social innovation is consequential and is said to induce social change, inventing new alternatives for social interactions and practices—such as doing, organizing, knowing, and framing (and often from a collective perspective) [30,31]. Moreover, social innovation induces reconfiguration of social practices, institutions, and networks in such a way that new modes of practice emerge [20]. Whereas technological and commercial innovations generally have financial and business motives, social innovation is more commonly concerned with the wellbeing of people, communities and society at large [32], and does not require diffusion through business organizations whose prime interest is making profits [17]. In contrary, social innovation frequently tends to deal with collective, societal challenges, such as climate change $[28,30]$. Therefore, social innovation is generally argued to have a high potential to address complex issues [17], and is gaining importance in relation to the innovative ability and sustainability of society [31].

Social innovations are often countercultural and self-consciously formed (by social groups) in response to unsustainable regimes [18]. As such, it does not cause surprise that social innovation is typically practiced by civil society groups with the aim to foster change towards a more inclusive and sustainable society, for instance to lower carbon emissions in society production [33]. Hewitt et al. [20] even argue that social innovation emphasizes the role of civil society in creating new ways of responding to crises and opportunities. In summary, it is fair to state that social innovation can be understood as the reconfiguring of social practices in response to societal challenges, with the aim of improving societal wellbeing through the engagement of civil society actors [34].

When taking the former into account, while addressing social innovation from an analytical perspective Hewitt et al. [20] argue that social innovation pertains to four key concepts, viz.: (i) crises and opportunities; (ii) the agency of civil society; (iii) reconfiguration of social practices, institutions and networks; and (iv) new ways of working that emerge from such a reconfiguration. Others view social innovation from a participative governance lens, focussing on co-creation and co-production with citizens and stakeholders. For instance, Voorberg et al. [35], (p. 3) see social innovation in terms of, "the creation of long-lasting outcomes that aim to address societal needs by fundamentally changing the relationships, positions and rules between the involved stakeholders, through an open process of participation, exchange and collaboration with relevant stakeholders, including end-users, thereby crossing organizational boundaries and jurisdictions."

Haxeltine et al. [36] conceived a theory on transformative social innovation (TSI) to induce transformative change in society. It theorizes how TSI processes lead to transformative change, and how social innovation networks, (bottom-up) initiatives and citizens are empowered. Compared 
to other analytical approaches in social innovation, TSI does not solely focus on the local or 'niche' level, but also acknowledges the system or 'regime' level, which contains elements (like institutions, social structures and incumbent actors) that strive to maintain the status quo and often form barriers to social innovation and the transformative change it seeks to incur. TSI pays to attention to four types of relations, viz.: (i) relations in social innovation initiatives (pertaining to empowerment, new social relations, and reflexive experimentation); (ii) relations in network formation (pertaining to building alliances, translocal connectivity, and discourse formation); (iii) relations to institutional change (pertaining to finding an institutional 'home', development of institutional change strategies, and the transposing of logics); and (iv) relations to the socio-material context (pertaining to diverse transformations, path dependencies, and re-emergence).

Taking the insights of the above mentioned concepts into account, a concise definition of social innovation is coined by the Bureau of European Policy Advisors [37], which states that, (in essence) "social innovations are innovations which are social in their ends and means". Given that means do not necessarily have to be intentional and goals are not necessarily (only) social [38], we argue that social innovation may also entail to issues like introducing new energy practices (i.e., related to the likes of production, storage, distribution, and use), new behaviors and relationships for supporting and managing social groups or new solutions that contribute to low carbon energy transition and at the same time to solving social problems. In addition to addressing energy problems we argue that social innovations typically also contribute to attaining social goals, like community empowerment, alleviating (energy) poverty, and increasing the general wellbeing of the community (somewhat related to 'climate co-benefits' [39]). In sum, we define social innovation in the realm of energy transitions as, "innovations that are social in their means and contribute to low carbon energy transition, civic empowerment and social goals pertaining to the general wellbeing of communities."

In the realm of energy transition this may relate to issues like social incentives (including 'green nudges') to stimulate behavioral change (e.g., to lower energy consumption), new social configurations (e.g., using social entrepreneurs or intermediaries to build social networks supportive to renewable energy), new organizational forms to stimulate low carbon energy services (e.g., renewable energy cooperatives), new forms of governance to stimulate transitions to low carbon economy (either at the local or regional scale; e.g., citizen self-governance or co-creation to co-design low carbon policy), novel policies and regulations to empower social groups to engage in low carbon energy activities. Another example stems from Seyfang and Haxeltine [18] who call for both improved insight into social innovation around technology within communities, as well as reflection on the uptake of such innovation beyond the local scale and its implications for energy transition.

\section{Lessons from Contributions to this Special Issue}

In this special issue, attention is given to social innovation highlighted from two perspectives: (a) a behavioral sciences perspective, and (b) a social sciences and governance perspective.

Within the behavioral sciences perspective attention is paid to the role of behavioral insights to succeed in energy transitions. When studying social innovation and the energy transition from a behavioral perspective, scholars tend to look at changes in attitude (e.g., the acceptance of new energy technology) and changes in behavior (e.g., lowering energy consumption or the actual adoption and use of clean energy technologies). Some studies look into the psychological mechanisms underlying these changes, including emotions, values, beliefs, and motivations. Other studies look into social innovations in the context of governance and policy, like the effectiveness of certain interventions or policies that can actually trigger change such as the previously mentioned green nudges. Relevant questions are: when and how do citizens rebel against sustainable energy initiatives? What psychological processes determine this behavior? Will it help to give people a nudge in the right direction, for example by making use of cognitive biases [22,40]? How to make energy-efficient appliances more attractive using social incentives? Or what role could (risk) communication play in the acceptance of large energy projects such as wind farms or $\mathrm{CO}_{2}$ capture and storage $[10,11,13]$ ? 
This special issue contains articles on both types of studies and contributes to behavioral sciences in several ways.

Within the social sciences and governance perspective the focus is on social, organizational, institutional, political, and policy aspects regarding experimentation and implementation of social innovations in the energy domain. This leads to questions like: To which extent does public support exist for experimentation and deployment of social innovations in the realm of energy transition? To what extent are social energy innovations at odds with values and existing institutions? Which social and policy barriers are preventing energy innovation breakthroughs? What social control models, governance arrangements, and/or policies can be used to accelerate the diffusion of proven energy innovations? In which ways and under which conditions can (particular) innovative social structures or practices-like citizen-led renewable energy supplying cooperatives-spur regional energy transition [18,41], what types of regulatory response do they evoke [5], and how does government respond to, and empower them [42-44]?

\subsection{Background Characteristics of Article Contributions to this Special Issue}

This special issue contains research from authors from all over the world. Insights are shared from Lebanon [45], Poland [46], India [47], Japan [48], Croatia, Spain [49], the UK [50,51], Portugal [52], and The Netherlands [53-57] leading to new perspectives on how social innovation is perceived in globally dispersed countries. Other contributions cover studies comprising of multiple countries like selected Member States within the European Union [58-60], countries within the OECD [61], or the European Union as an entity itself [62]. When we understand-and compare-social innovation in a cross-national, cultural context, we can develop a stronger and richer understanding of the dynamics that shape the policies and transformation strategies to foster the adoption of technological energy innovations.

Article contributions to this special issue came from a wide set of academic disciplines from the behavioral and social sciences, like law $[49,62]$, psychology [46,50,51,56], sociology [45,53], governance and policy studies [54,57,59], economics [48,60,63], econometrics [61], anthropology [47,52], ethics [56], geography [55,64], and environmental sciences [58].

\subsubsection{Use of Theory}

In articles belonging to this special issue, the authors used a broad set of theories. Theoretical approaches from the behavioral sciences concerned (elements of) user oriented theories and theory of planned behavior [65]. Theoretical approaches from the social sciences used concerned diffusion of innovations [66], actor-network theory [67], sociology of translation [68], endogenous development [69], and asset-based community development [70]. Theoretical approaches from governance and policy studies concerned multi-level governance [71] and policy networks [72,73]. Theoretical approaches from (institutional) economics concern social ecological systems [74] and the institutional analysis and development framework [75], which are concepts that both derive from Nobel Prize Winner Elinor Ostrom. The functional approach [76] was used a conceptual approach in legal sciences. This special issue also saw the use of strategic niche management $[77,78]$ and the multi-level perspective [79] as conceptual approached from innovation and transition studies. Finally, this special issue is also home to the presentation of new-often eclectic-theoretical frameworks addressing issues like regional governance assessment [54], a typology on intermediaries supporting civic action [57], and a framework to analyze how energy projects influence people who live or work nearby [56].

\subsubsection{Methods Used}

18 out of 20 articles of this special issue comprised research articles. 12 of these articles concerned qualitative research methods, and quantitative research methods are used in 5 other articles. 3 articles concerned review articles presenting systematic academic literature reviews, leading to development of 
conceptual frameworks and propositions that can be of use in future research [50,60,64]. 2 articles used and analyzed serious games [50,59]. From the research articles, 11 used case study research designs (with 8 single case studies and 3 multiple or cross case studies), comprising of various kinds of data collection and analysis, like interviews, participatory research, legal analysis, narrative approaches, and expert validations. Other research designs in articles contributing to this special issue concern surveys [46,48,50,59], econometric analysis [61], longitudinal statistical analysis [58], and serious gaming [59].

\subsection{Insights on Social Innovation}

When regarding social innovation the contributions to this special issue presents a number of key issues: (i) technological innovation leading to new market models, actor configurations and institutional settings creating room for social innovation; (ii) new governance arrangements; (iii) community energy, its impact, implications, and social incentives and policy to empower it; (iv) new participative research approaches to test and learn from livings labs and best practices; (v) green nudges to stimulate behavioral change; and finally (vi) serious energy games.

Lavrijssen and Parra [62] address smart energy systems that lead to social innovation in terms of new market models (like peer to peer trading of locally generated energy), new actor configurations, and coordinated citizen action like community energy. The authors argue that the electricity sector is in a transition towards a Smart Energy System in which new roles are evolving pertaining to private and institutional actors. In this transition technological innovations enable social innovations such as peer to peer trading and the participation in local energy collectives, on the regulation of the rights and obligations of consumers and prosumers in the electricity sector (for a comprehensive account on regulatory response to innovations in the EU energy market a designated special issue in the same academic journal, see: https://www.mdpi.com/journal/sustainability/special_issues/regulatory_ responses; [5]). In their article, Lavrijssen and Parra identify the main radical innovations in the electricity market and analyze the legal and related non-legal obstacles that impede the empowerment of energy consumers, prosumers, and community energy action.

In their contribution Acosta et al. [63] introduce Integrated Community Energy Systems (ICES) and the role of community energy therein. ICES are an emerging form of local energy systems focusing on the collective use of distributed energy resources. They can be perceived as socio-technical systems that have a high potential to advance local energy systems into socially inclusive, environmentally-friendly energy systems that at the same time stimulate local economies. While there is an analogy between energy in ICES and other common goods such as natural resources, it is not clear yet to what extent the existing theoretical framework for socio-ecological systems on the commons [74] accounts for the specificities of common resources in ICES. The authors propose a framework and a strategic plan that can be used to design and implement ICES.

Lammers and Hoppe [60] present the results of a systematic literature review into governance and planning of local energy systems paying attention to several aspects, i.e., policy entrepreneurs, knowledge brokers, network and process management, boundary spanning, and end user involvement. They apply the concepts of 'action arenas' and 'institutional rules' from Elinor Ostrom's institutional analysis and development framework [75] to analyze practices of local and district level energy governance (i.e., planning and implementation). Like Acosta et al. [63] they use Ostrom's conceptual notions on energy as a commons and perceive local energy systems as socio-technical systems. The review article develops 15 propositions for future research.

In their contribution Leeuw and Groenleer [54] address the governance of regional energy-neutral housing initiatives. They develop a framework to analyze regional governance of energy innovations, and apply it in a cross case analysis of three provinces in The Netherlands. The authors argue that regional governance can be seen as an important social innovation in itself, with regions serving as 'living labs' for innovation, technologically, as well as socially. The idea then is to experiment with and learn from local and regional solutions. To find out what works and what does not, also in terms 
of new configurations (e.g., new roles, new responsibilities, and new relationships between actors). The results of the case study analysis reveal that the regional governance of energy-neutral housing initiatives is primarily driven by existing social networks in the regions, and is less determined by situational factors like local characteristics of the built environment. It seems that regional governance has generated solutions that are supported by regional actors. While attempts have been made to experiment with and learn from local and regional solutions, there is a limited degree of social innovation in terms of new configurations (more particularly in terms of new roles, new responsibilities and new relationships). In all of the three regions, actors experienced difficulty early on with regard to achievement of energy-neutral housing, at the stage of framing, assessment and comprehension of the agenda. The authors argue that this is because central government was usually the starting point for action in the region. This shows that regional governance processes, notwithstanding the ongoing decentralization of the energy system, still occur primarily in the shadow of developments at the national level.

Wierling et al. [58] study community energy and its impact on energy transition. The article provides empirical evidence of activities by energy cooperatives in four different European countries. The results show that energy cooperatives are important enablers of the energy transition. However, the historic development of the number of energy cooperatives is found to coincide with the development of supportive schemes by government. As these schemes are tightened or removed there is uncertainty about the role of cooperatives. In reaction to the removal or tightening up of the incentives schemes, energy cooperatives respond by diversifying their portfolios and/or increasing their numbers of shares and members, to maintain cash flows, and as an alternative to terminating their activities altogether. Gabaldón-Estevan et al. [49] also addressed community energy and energy cooperatives in their study (i.e., by mentioning the case of the cooperative SOM Energia). They found that Spanish energy policy is too much responding to the incumbent energy lobby's demands for protection for its investment and maintenance of its dominant position. This has resulted in a reduction in the number of investors combined with a lack of trust in both local and foreign investors in the sustainable energy sector, also affecting social innovations in energy transitions (negatively). Notwithstanding, the renewable energy cooperative community has been growing, arguably dissatisfied in response to policy developments in domestic energy markets.

Van der Waal et al. [53] present insights in how energy initiatives develop technological innovations by bringing together local actors and creating a fit to local circumstances. Their article reveals that outcomes of the innovation processes are dependent on the networking capacities of the energy initiatives, and how well they fit with external circumstances and opportunities. The authors present five lessons for technological innovation with grassroots organizations, viz. (i) form links with the local environment; (ii) extensively scrutinize plans; (iii) create tangible proof of alignments; (iv) position the project as beneficial to as many actors as possible; and (v) adjust the level of ambition to the strength of the actor network. Warbroek et al. [57] study social innovation in the form of community energy, local low carbon energy initiatives (LLCEIs), and agency by intermediaries to empower them. The authors present new insights: theoretical—pertaining to a new intermediaries typology; and empirical-pertaining to the roles of intermediaries towards community energy in two provinces in The Netherlands.

Kooij et al. [55] study new policy instrument to support community energy, and analyze how they play out on niche-regime interaction concerning renewable energy project development by grassroots energy initiatives. Like TSI theorists $[26,30,36]$ the authors focus on social innovation and address its implications from the perspective of niche development, engaging with regime system forces. The authors present the case of The Netherlands in which citizens have experimented with various kinds of innovations in the past few years to organize collective production of renewable energy, including shared wind power and solar PV installations. However, most of these attempts failed, mainly for legal reasons and tax rules, that had a negative impact on the financial-economic business case of projects. Yet, one supportive policy model for solar PV on collective roofs was implemented 
more widely: the so-called 'postcode rose'. In the end the authors argue that the various attempts for collective solar PV, with different degrees of success present a key aspect of niche development, namely that of associational work (i.e., circulation and mobilization) focused on regime change. In conclusion, the innovation path supported by the implementation of the 'postcode rose' emphasizes the importance of the political and associational dimensions in the energy transition and in (conceptual) transition thinking.

In their article, Sareen et al. [52] explore challenges in transitioning towards future energy systems applied to a solar test field within an eco-community in Portugal. In terms of social innovation, this should be seen as a new research approach focussing on a best practice. The authors argue that their research approach speaks to building epistemological complementarities between applied researchers and practicing agents. The approach also problematizes linking across scale between a community and institutionalising powers, and calls for actionable efforts that integrate systems thinking and power dynamics towards transformation. This type of research can arguably be seen as social innovation in itself and resembles practices of action research. In their article, Winkler et al. address innovation to integrate local farmers' views in policymaking about renewable energy [47]. They argue that smallholder farmers' motivation to produce and use renewable energy is essentially high, and that their perspective should be integrated in the design of renewable energy supporting policies and related programs to utilize local natural resources more effectively and promote the transition towards renewable energy. Social innovation can help smallholder farmers to reach this goal.

Two articles of this special issue introduce serious gaming as a social innovative way to 'nudge' people toward sustainable behavior. As stated earlier, behavioral studies interested in social innovation and the energy transition study the design and effectiveness of green nudging; interventions that make green behavior easier and more convenient than the status quo. Examples of (technological) 'green nudging' are the default setting on washing machines and the use of master switches in hotel rooms [80]. Many washing machines are programmed with warm water as the default setting while the-more sustainable - cold-water option requires changing the settings. A green nudge would be to change the settings in such a way that cold water becomes the default and switching to warm water becomes the 'hassle'. Another example of a green nudge is the use of master switches in hotel rooms. In many hotels, guests have to activate the power in the room with their key when they arrive. This makes it easier (unavoidable actually) to turn off the lights and air-conditioning when they (ibid.). This special issue presents two articles on serious energy gaming as a form of social innovation vis-à-vis green nudging [50,59].

Bekebrede et al. [59] developed and tested the use of a simulation game—entitled 'GO2Zero' [81] to increase the understanding of the complexity of low carbon energy transition at city district level. Their article suggests that simulation games could become valuable instruments in local energy transition processes as they offer a safe and fun environment for novices and experts to jointly experiment with the challenges in this process. Playing these games and stakeholders gaining experience with its rules and practices can be supportive to the design of the transition process by helping actors to formulate goals, generate collaborative strategies, and coherent decision making. In their article, Boomsma et al. showed the use of serious games as 'nudge' to change energy behaviors of social housing residents [50]. They conclude that serious energy games can become effective tools if clear actionable solutions for reducing energy bills are provided to the users/players. However, the study also revealed that not all residents playing the game were enthusiastic. This was for reasons related to time pressure, negative perceptions of gaming, and limited confidence in using computers or tablets. As such, uptake of a serious energy game may encounter challenges.

\section{Conclusions and Implications}

This guest editorial set out with the questions, "What does social innovation mean in the face of energy transition, and what are its implications?" At the end of the conceptual section on social innovation, a definition was adopted which addresses social innovation in the realm of energy 
transitions. It concerns innovation that is social in its means and which contributes to low carbon energy transition, civic empowerment, and social goals pertaining to the general wellbeing of communities. So, in addition to contributing to low carbon energy transition we argue that social innovation seeks to attain particular social goals, like community empowerment, alleviating (energy) poverty, (energy) justice, social equality, and increasing the wellbeing of local communities.

This special issue yields 20 article contributions by authors from a wide range of academic disciplines within the behavioral and social sciences. From these contributions, key topics relevant to social innovation were derived. They pertain to the following: (i) technological innovation leading to new market models, actor configurations and institutional settings creating room for social innovation; (ii) new governance arrangements; (iii) community energy, its impact, implications, and social incentives and policy to empower it; (iv) new participative research approaches to test and learn from livings labs and best practices; (v) 'green nudges' to stimulate behavioral change; and finally (vi) serious energy games.

\section{Suggestions for Future Research}

From the contributions suggestions for future research were drawn. They address issues relevant to social innovation like monitoring civic action (i.e., community energy performance), drawing lessons from best practices, network formation, civic action and agency, experimentation and reconfiguration of social practices, governance arrangements and decision-making arenas, and public policy empowering civic initiatives and action (in particular energy communities and renewable energy cooperatives), studying the impact of 'green nudges' on behavioral change, researching the impact of novel incentives, approaches and policy into stimulating low carbon energy transition while at the same time contributing to social goals like alleviating energy poverty. In addition, there is a need to integrate the sociocultural dimension into social innovation research in the domain of energy transitions, and to study social innovations in cross-cultural comparative research.

More specific suggestions for future research on social innovation in the realm of energy transitions pertain to the following. Winkler et al. [47] suggest to study the impact of bottom-up exploration of smallholder livelihoods and available renewable resources on farmers' (motivation to) use and acceptance of renewable energy. Future research is also suggested on (multiple) cases in which social innovation is used at university campuses that is progressing to sustainable futures, with an eye on best practices and identifying and addressing political barriers that impede these developments [64]. In a similar vein, Sareen et al. [52] suggest learning from living labs in which social innovations are tested at the community level, and discovering whether proactive approaches and interventions are effective in meeting their social and energy goals.

Regarding research on community energy, and renewable energy cooperatives in particular, Wierling et al. [58] suggest to track and illuminate how energy cooperatives contribute to low carbon energy transitions and how they prosper, also in the light of diminishing government programs and supportive schemes available. Van der Waal et al. [53] suggest further research into whether (and if yes, what aspects of) locally configured innovations, particularly local energy community, disperse, and whether policies to support these social innovations are effective and have (lasting) impact. In the light of national governments providing increasingly less incentives and support schemes to support renewable energy projects it was suggested by Gabaldón-Estevan et al. to analyze the effects of this policy development on the resilience of REScoops and citizens vis-à-vis the efforts they make to foster energy transition like the adoption of renewable energy technology and renewable energy project development [49]. More empirical research is also needed to elaborate the intermediaries typology in support of renewable energy cooperatives, as coined by Warbroek et al. [57], and to conduct more research into policies that empower and support grassroots initiatives that have the desire to develop renewable energy projects (derived from the article by Kooij et al. [55]).

More in general, there is a need to conduct future (empirical) research using conceptual frameworks that were conceived and presented in a number of article contributions to this 
special issue, like the framework on integrated community energy systems [63], the framework on regional governance arrangements [54], the framework on the relationship between people's values, the implications of energy projects for these values and people's emotional response to energy projects [56], apply the typology on intermediary roles in support of civic action (i.e., community energy initiatives) [57], and to test propositions on governance and institutions in local energy planning and implementation [60].

Finally, based on the two articles in this special issue that address the use of serious energy games $[59,60]$ we suggest more interdisciplinary research and user-led approaches are needed, focusing on the design of successful and engaging serious energy games, as well as experimenting with different strategies and instruments in serious energy gaming, and to analyze their effects.

Author Contributions: T.H. and G.d.V. wrote Section 1, Section 2, Section 3, and Section 4 together. T.H. and G.d.V. co-edited the special issue on "Social Innovations in the Energy Transition" (https://www.mdpi.com/ journal/sustainability/special_issues/Social_innovations_energy_transition).

Funding: The special issue and this guest editorial received financial support from the Delft Energy Initiative of Delft University of Technology, at Delft, The Netherlands.

Acknowledgments: The authors would like to thank Paulien Herder, Freek Swart, the authors who contributed to the special issue, the attendants of the 'Social Innovation in the Energy Transition' symposium organized in April 2017 at Delft University of Technology, and a great number of anonymous reviewers for their contributions to this special issue.

Conflicts of Interest: The authors declare no conflict of interest.

\section{References}

1. United Nations. Sustainable Development Goals; 17 Goals to Transform Our World. Available online: https: / / www.un.org/sustainabledevelopment/sustainable-development-goals/ (accessed on 8 August 2018).

2. United Nations Climate Change Conference (UNFCCC). Cop24 Katowice United Nations Climate Chane Conference; United Nations, Ed.; Framework Convention on Climate Change (FCCC): Bonn, Germany, 2018.

3. United Nations Climate Change. 175 States Sign Paris Agreement; Announcement/22 apr, 2016; Framework Convention on Climate Change (FCCC): Bonn, Germany, 2016.

4. United Nations Climate Change. Adoption of the Paris Agreement; Framework Convention on Climate Change (FCCC): Bonn, Germany, 2015; Volume FCCC/CP/2015/L.9/Rev.1, pp. 1-32.

5. Hoppe, T.; Butenko, A.; Heldeweg, M. Innovation in the European Energy Sector and Regulatory Responses to It: Guest Editorial Note. Sustainability 2018, 10, 416. [CrossRef]

6. Wüstenhagen, R.; Wolsink, M.; Bürer, M.J. Social acceptance of renewable energy innovation: An introduction to the concept. Energ Policy 2007, 35, 2683-2691. [CrossRef]

7. Wolsink, M. The research agenda on social acceptance of distributed generation in smart grids: Renewable as common pool resources. Renew. Sustain. Energy Rev. 2012, 16, 822-835. [CrossRef]

8. Sovacool, B.K. What are we doing here? Analyzing fifteen years of energy scholarship and proposing a social science research agenda. Energy Res. Soc. Sci. 2014, 1, 1-29. [CrossRef]

9. Huijts, N.M.; Molin, E.J.; Steg, L. Psychological factors influencing sustainable energy technology acceptance: A review-based comprehensive framework. Energy Res. Soc. Sci. 2012, 16, 525-531. [CrossRef]

10. De Vries, G.; Terwel, B.W.; Ellemers, N. Perceptions of manipulation and judgments of illegitimacy: Pitfalls in the use of emphasis framing when communicating about $\mathrm{CO}_{2}$ capture and storage. Environ. Commun. 2016, 10, 206-226. [CrossRef]

11. De Vries, G.; Terwel, B.W.; Ellemers, N. Spare the details, share the relevance: The dilution effect in communications about carbon dioxide capture and storage. J. Environ. Psychol. 2014, 38, 116-123. [CrossRef]

12. Terwel, B.W.; Harinck, F.; Ellemers, N.; Daamen, D.D. Going beyond the properties of co2 capture and storage (ccs) technology: How trust in stakeholders affects public acceptance of ccs. Int. J. Greenh. Gas Control 2011, 5, 181-188. [CrossRef]

13. De Vries, G. How positive framing may fuel opposition to low-carbon technologies: The boomerang model. J. Language Soc. Psychol. 2017, 36, 28-44. [CrossRef] 
14. Meadowcroft, J. What about the politics? Sustainable development, transition management, and long term energy transitions. Policy Sci. 2009, 42, 323-340. [CrossRef]

15. Negro, S.O.; Hekkert, M.P.; Smits, R.E. Explaining the failure of the dutch innovation system for biomass digestion-A functional analysis. Energ Policy 2007, 35, 925-938. [CrossRef]

16. Faber, A.; Hoppe, T. Co-constructing a sustainable built environment in the netherlands-Dynamics and opportunities in an environmental sectoral innovation system. Energ Policy 2013, 52, 628-638. [CrossRef]

17. Mulgan, G.; Tucker, S.; Ali, R.; Sanders, B. Social Innovation: What It Is, Why It Matters and How It Can Be Accelerated; Skoll Centre for Social Entrepreneurship, The Young Foundation: London, UK, 2007.

18. Seyfang, G.; Haxeltine, A. Growing grassroots innovations: Exploring the role of community-based initiatives in governing sustainable energy transitions. Environ. Plan. C Gov. Policy 2012, 30, 381-400. [CrossRef]

19. Maruyama, Y.; Nishikido, M.; Iida, T. The rise of community wind power in Japan: Enhanced acceptance through social innovation. Energy Policy 2007, 35, 2761-2769. [CrossRef]

20. Hewitt, R.J.; Bradley, N.; Compagnucci, A.B.; Barlagne, C.; Ceglarz, A.; Cremades, R.; McKeen, M.; Otto, I.M.; Slee, B. Social Innovation in Community Energy in Europe: A Review of the Evidence; James Hutton Institute: Aberdeen, UK, 2018.

21. Brummer, V.; Herbes, C.; Gericke, N. Conflict handling in renewable energy cooperatives (recs): Organizational effects and member well-being. Ann. Public Coop. Econ. 2017, 88, 179-202. [CrossRef]

22. Schubert, C. Green nudges: Do they work? Are they ethical? Ecol. Econ. 2017, 132, 329-342. [CrossRef]

23. Martinelli, F. Social innovation or social exclusion? Innovating social services in the context of a retrenching welfare state. In Challenge Social Innovation; Springer: Berlin/Heidelberg, Germany, 2012; pp. 169-180.

24. Mulgan, G. Social innovation theories: Can theory catch up with practice? In Challenge Social Innovation; Springer: Berlin/Heidelberg, Germany, 2012; pp. 19-42.

25. Mulgan, G. The process of social innovation. Innov. Technol. Gov. Glob. 2006, 1, 145-162. [CrossRef]

26. Haxeltine, A.; Avelino, F.; Pel, B.; Dumitru, A.; Kemp, R.; Longhurst, N.; Chilvers, J.; Wittmayer, J.M. A Framework for Transformative Social Innovation; TRANSIT working paper; TRANSIT: Montreal, QC, Canada, 2016.

27. Bergman, N.; Markusson, N.; Connor, P.; Middlemiss, L.; Ricci, M. Bottom-up, social innovation for addressing climate change. In Proceedings of the Sussex Energy Group conference, Sussex, UK, 25-26 February 2010; pp. 25-26.

28. Cajaiba-Santana, G. Social innovation: Moving the field forward. A conceptual framework. Technol. Forecast. Soc. Chang. 2014, 82, 42-51. [CrossRef]

29. Hochgerner, J. New combinations of social practices in the knowledge society. In Challenge Social Innovation; Springer: Berlin/Heidelberg, Germany, 2012; pp. 87-104.

30. Avelino, F.; Wittmayer, J.M.; Pel, B.; Weaver, P.; Dumitru, A.; Haxeltine, A.; Kemp, R.; Jørgensen, M.S.; Bauler, T.; Ruijsink, S. Transformative social innovation and (dis) empowerment. Technol. Forecast. Soc. Chang. 2017. (In press) [CrossRef]

31. Howaldt, J.; Schwarz, M. Social innovation and its relationship to social change. Change 2016, 1, 3.

32. Dawson, P.; Daniel, L. Understanding social innovation: A provisional framework. Int. J. Technol. Manag. 2010, 51, 9-21. [CrossRef]

33. Harnmeijer, J.; Harnmeijer, A.; Loyd, C. Towards a global database of community-led renewable energy development. Reg. Mag. 2012, 287, 16-18. [CrossRef]

34. Polman, N.; Slee, B.; Kluvánková, T.; Dijkshoorn, M.; Nijnik, M.; Gezik, V.; Soma, K. Report d2. 1: Classification of social innovations for marginalized rural areas. In Deliverable of the Project Social Innovation in Marginalised Rural Areas (Simra); Simra: Brussels, Belgium, 2017.

35. Voorberg, W.H.; Bekkers, V.J.; Tummers, L.G. A systematic review of co-creation and co-production: Embarking on the social innovation journey. Public Manag. Rev. 2015, 17, 1333-1357. [CrossRef]

36. Haxeltine, A.; Pel, B.; Dumitru, A.; Avelino, F.; Kemp, R.; Bauler, T.; Kunze, I.; Dorland, J.; Wittmayer, J.; Jørgensen, M.S. Towards a Tsi Theory: A Relational Framework and 12 Propositions; TRANSIT working paper; TRANSIT: Montreal, QC, Canada, 2017.

37. Hubert, A. Empowering People, Driving Change: Social Innovation in the European Union, the Bureau of European Policy Advisers. Report. Available online: http:/ /ec.europa.eu/bepa/pdf/publications_pdf/ social_innovation.pdf (accessed on 20 December 2010). 
38. Franz, H.-W.; Hochgerner, J.; Howaldt, J. Challenge Social Innovation. Potentials for Business, Social Entreprenurship, Welfare and Civil Society; Springer: Berlin/Heidelberg, Germany, 2012.

39. West, J.J.; Smith, S.J.; Silva, R.A.; Naik, V.; Zhang, Y.; Adelman, Z.; Fry, M.M.; Anenberg, S.; Horowitz, L.W.; Lamarque, J.-F. Co-benefits of mitigating global greenhouse gas emissions for future air quality and human health. Nat. Clim. Chang. 2013, 3, 885-889. [CrossRef] [PubMed]

40. Goldstein, D.G.; Johnson, E.J.; Herrmann, A.; Heitmann, M. Nudge your customers toward better choices. Harv. Bus. Rev. 2008, 86, 99-105.

41. Walker, G.; Devine-Wright, P.; Hunter, S.; High, H.; Evans, B. Trust and community: Exploring the meanings, contexts and dynamics of community renewable energy. Energ Policy 2010, 38, 2655-2663. [CrossRef]

42. Hoppe, T.; Graf, A.; Warbroek, B.; Lammers, I.; Lepping, I. Local governments supporting local energy initiatives; lessons from the best practices of saerbeck (germany) and lochem (The Netherlands). Sustainability 2015, 7, 1900-1931. [CrossRef]

43. Warbroek, B.; Hoppe, T. Modes of governing and policy of local and regional governments supporting local low-carbon energy initiatives; exploring the cases of the dutch regions of overijssel and fryslân. Sustainability 2017, 9, 75. [CrossRef]

44. Boehnke, R.F.; Hoppe, T.; Brezet, H.; Blok, K. Good practices in local climate mitigation action by small and medium-sized cities; exploring meaning, implementation and linkage to actual lowering of carbon emissions in thirteen municipalities in the netherlands. J. Clean. Prod. 2019, 207, 630-644. [CrossRef]

45. Elmustapha, H.; Hoppe, T.; Bressers, H. Understanding stakeholders' views and the influence of the socio-cultural dimension on the adoption of solar energy technology in lebanon. Sustainability 2018, 10, 364. [CrossRef]

46. Kowalska-Pyzalska, A. An empirical analysis of green electricity adoption among residential consumers in poland. Sustainability 2018, 10, 2281. [CrossRef]

47. Winkler, B.; Lewandowski, I.; Voss, A.; Lemke, S. Transition towards renewable energy production? Potential in smallholder agricultural systems in west bengal, india. Sustainability 2018, 10, 801. [CrossRef]

48. Nakano, R.; Miwa, T.; Morikawa, T. Comparative analysis on citizen's subjective responses related to their willingness to pay for renewable energy in japan using latent variables. Sustainability 2018, 10, 2423. [CrossRef]

49. Gabaldón-Estevan, D.; Peñalvo-López, E.; Alfonso Solar, D. The spanish turn against renewable energy development. Sustainability 2018, 10, 1208. [CrossRef]

50. Boomsma, C.; Hafner, R.; Pahl, S.; Jones, R.V.; Fuertes, A. Should we play games where energy is concerned? Perceptions of serious gaming as a technology to motivate energy behaviour change among social housing residents. Sustainability 2018, 10, 1729. [CrossRef]

51. Oliveira, S.; Marco, E. Role of 'community spaces' in residents' adaptation to energy-efficient heating technologies-Insights from a uk low-energy housing development. Sustainability 2018, 10, 934. [CrossRef]

52. Sareen, S.; Baillie, D.; Kleinwächter, J. Transitions to future energy systems: Learning from a community test field. Sustainability 2018, 10, 4513. [CrossRef]

53. Van der Waal, E.; van der Windt, H.; van Oost, E. How local energy initiatives develop technological innovations: Growing an actor network. Sustainability 2018, 10, 4577. [CrossRef]

54. De Leeuw, L.; Groenleer, M. The regional governance of energy-neutral housing: Toward a framework for analysis. Sustainability 2018, 10, 3726. [CrossRef]

55. Kooij, H.-J.; Lagendijk, A.; Oteman, M. Who beats the dutch tax department? Tracing 20 years of niche-regime interactions on collective solar pv production in the netherlands. Sustainability 2018, 10, 2807. [CrossRef]

56. Perlaviciute, G.; Steg, L.; Contzen, N.; Roeser, S.; Huijts, N. Emotional responses to energy projects: Insights for responsible decision making in a sustainable energy transition. Sustainability 2018, 10, 2526. [CrossRef]

57. Warbroek, B.; Hoppe, T.; Coenen, F.; Bressers, H. The role of intermediaries in supporting local low-carbon energy initiatives. Sustainability 2018, 10, 2450. [CrossRef]

58. Wierling, A.; Schwanitz, V.; Zeiß, J.; Bout, C.; Candelise, C.; Gilcrease, W.; Gregg, J. Statistical evidence on the role of energy cooperatives for the energy transition in european countries. Sustainability 2018, 10, 3339. [CrossRef]

59. Bekebrede, G.; van Bueren, E.; Wenzler, I. Towards a joint local energy transition process in urban districts: The go2zero simulation game. Sustainability 2018, 10, 2602. [CrossRef] 
60. Lammers, I.; Hoppe, T. Analysing the institutional setting of local renewable energy planning and implementation in the eu: A systematic literature review. Sustainability 2018, 10, 3212. [CrossRef]

61. Sung, B.; Park, S.-D. Who drives the transition to a renewable-energy economy? Multi-actor perspective on social innovation. Sustainability 2018, 10, 448. [CrossRef]

62. Lavrijssen, S.; Carrillo Parra, A. Radical prosumer innovations in the electricity sector and the impact on prosumer regulation. Sustainability 2017, 9, 1207. [CrossRef]

63. Acosta, C.; Ortega, M.; Bunsen, T.; Koirala, B.P.; Ghorbani, A. Facilitating energy transition through energy commons: An application of socio-ecological systems framework for integrated community energy systems. Sustainability 2018, 10, 366. [CrossRef]

64. Mohammadalizadehkorde, M.; Weaver, R. Universities as models of sustainable energy-consuming communities? Review of selected literature. Sustainability 2018, 10, 3250. [CrossRef]

65. Ajzen, I. From intentions to actions: A theory of planned behavior. In Action Control; Springer: Berlin/Heidelberg, Germany, 1985; pp. 11-39.

66. Rogers, E.M. Diffusion of Innovations, 5th Revised edition ed.; Simon \& Schuster Ltd: New York City, NY, USA, 2003.

67. Latour, B. Reassembling the Social: An Introduction to Actor-Network-Theory; Oxford University Press: Oxford, UK, 2005.

68. Callon, M. Some elements of a sociology of translation: Domestication of the scallops and the fishermen of st brieuc bay. Sociol. Rev. 1984, 32, 196-233. [CrossRef]

69. Ray, C. Endogenous development in the era of reflexive modernity. J. Rural Stud. 1999, 15, 257-267. [CrossRef]

70. Mathie, A.; Cunningham, G. From clients to citizens: Asset-based community development as a strategy for community-driven development. Dev. Pract. 2003, 13, 474-486. [CrossRef]

71. Hooghe, L.; Marks, G.; Marks, G.W. Multi-Level Governance and European Integration; Rowman \& Littlefield: Blue Ridge Summit, PA, USA, 2001.

72. Marsh, D.; Rhodes, R.A.W. Policy Networks in British Government; Clarendon Press: Wotton-under-Edge, UK, 1992.

73. Kickert, W.J.M.; Klijn, E.-H.; Koppenjan, J.F.M. Managing Complex Networks: Strategies for the Public Sector; SAGE: London, UK; Thousand Oaks, CA, USA; New Delhi, India, 1997; p. 206.

74. Ostrom, E. A general framework for analyzing sustainability of social-ecological systems. Science 2009, 325, 419-422. [CrossRef] [PubMed]

75. Ostrom, E. Understanding Institutional Diversity; Princeton University Press: Princeton, NJ, USA, 2009 ; p. 376.

76. Bassiouni, M.C. A functional approach to general principles of international law. Mich. J. Int. Law 1989, 11,768 .

77. Kemp, R.; Schot, J.; Hoogma, R. Regime shifts to sustainability through processes of niche formation: The approach of strategic niche management. Technol. Anal. Strat. Manag. 1998, 10, 175-198. [CrossRef]

78. Raven, R. Strategic Niche Management for Biomass Technical University Eindhoven (TU/E); TU Eindhoven: Eindhoven, The Netherlands, 2005.

79. Geels, F. Technological transitions as evolutionary reconfiguration processes: A multi-level perspective and a case-study. Res. Policy 2002, 31, 1257-1274. [CrossRef]

80. McKenzie-Mohr, D.; Schultz, P.W. Choosing effective behavior change tools. Social Marketing Quarterly 2014, 20, 35-46. [CrossRef]

81. Van Bueren, E.; Bekebrede, G.; Wenzler, I. Serious Games as Instrument to Support Energy Retrofitting Lessons from the go2zero City-Zen Game; Eco Connect London: London, UK, 2017.

(C) 2018 by the authors. Licensee MDPI, Basel, Switzerland. This article is an open access article distributed under the terms and conditions of the Creative Commons Attribution (CC BY) license (http://creativecommons.org/licenses/by/4.0/). 